\title{
ANALISIS KEMAMPUAN PENALARAN dan BERPIKIR KREATIF MATEMATIS SISWA DALAM PEMBELAJARAN PENEMUAN TERBIMBING
}

\author{
Fernanda Siallagan $^{1}$, Bornok Sinaga ${ }^{2}$, Waminton Rajagukguk ${ }^{2}$
}

\begin{abstract}
ABSTRAK
Penelitian ini bertujuan untuk menganalisis: 1) kemampuan penalaran dan berpikir kreatif matematis siswa yang diajar dengan menggunakan model penemuan terbimbing. 2) proses jawaban siswa dalam menyelesaikan masalah matematika. 3) kesulitan dari kemampuan penalaran dan berpikir kreatif matematis siswa dalam memecahkan masalah matematika. Penelitian ini merupakan penelitian kualitatif deskriptif. Subjek dalam penelitian ini melibatkan siswa SMP Parulian 1 Medan Kelas VII sebanyak 28 orang siswa yang diberi perlakuan pembelajaran penemuan terbimbing pada semester ganjil tahun pelajaran 2020/2021. Hasil penelitian menunjukkan bahwa: 1) Kemampuan penalaran matematis siswa dengan model penemuan terbimbing pada kategori tinggi ada 8 siswa, pada kategori sedang ada 14 siswa, dan pada kategori rendah ada 6 siswa. Sedangkan kemampuan berpikir kreatif matematis siswa dengan model penemuan terbimbing terdapat 5 siswa pada kategori tinggi, 10 siswa pada kategori sedang, dan 13 siswa pada kategori rendah. 2) proses jawaban siswa dideskripsikan maka disimpulkan bahwa: a) tingkat penalaran siswa pada kategori tinggi adalah nominan siswa menyelesaikan masalah mencapai indikator penalaran dan berpikir kreatif dengan sedikit mengalami kesulitan. b) tingkat penalaran siswa pada kategori sedang adalah nominan siswa menyelesaikan masalah pada indikator mampu mengajukan dugaan (conjecture), mampu memberikan alasan atau bukti terhadap kebenaran suatu pernyataan, mampu menarik kesimpulan dari suatu pernyataan, dan mampu memeriksa keshahihan argument. Sedangkan pada kemampuan berpikir kreatif matematis tingkat sedang bahwa proses jawaban siswa memenuhi tahapan persiapan, inkubasi, iluminasi dan ada beberapa siswa tidak mencapai tahapan verifikasi c) tingkat penalaran siswa pada kategori rendah adalah nominan siswa tidak mampu mencapai indikator penalaran, sedangkan siswa dengan kemampuan berpikir kreatif matematis tingkat rendah dengan proses jawaban yang tidak memenuhi tahapan iluminasi dan verifikasi. 3) Kesulitan yang dialami oleh siswa yaitu pada kategori sedang dan rendah yang mencakup pada kesulitan fakta, konsep, prinsip, dan prosedur.
\end{abstract}

Kata Kunci: Penelitian Kualitatif Deskriptif, Kemampuan Penalaran Matematis, Kemampuan Berpikir Kreatif matematis, Penemuan Terbimbing

\section{PENDAHULUAN}

Matematika merupakan ilmu yang berperan penting dalam pendidikan. Matematika bersifat universal yang memiliki karakteristik untuk menuntut bernalar, berpikir logis, analitis, sistematis, kritis, inovatif, dan kreatif yang berguna bagi kehidupan manusia dan juga mendasari perkembangan teknologi modern, serta mempunyai peran penting dalam berbagai disiplin dan memajukan daya pikir manusia.

Menurut Cornelius (Abdurrahman, 2012) mengemukakan bahwa lima alasan perlunya belajar matematika yaitu (1) sarana berpikir yang jelas dan logis, (2) sarana untuk memecahkan masalah kehidupan sehari-hari, (3) sarana mengenal pola-pola hubungan dan generalisasi pengalaman, (4) sarana untuk mengembangkan kreativitas, dan (5) sarana untuk meningkatkan kesadaran terhadap perkembangan budaya.

Sinaga (2007) menyatakan "Banyak faktor sebagai sumber penyebab kesulitan belajar. Sebagai contoh yang bersumber dari luar diri siswa, misalnya proses

\footnotetext{
${ }^{1}$ Corresponding Author: Fernanda Siallagan

Guru Matematika SMKS Parulian 1 Medan, Medan, 20217, Indonesia E-mail: fernandasiallagan19(@gmail.com
}

${ }^{2}$ Co-Author: Bornok Sinaga \& Waminton Rajagukguk Program Studi Pendidikan Matematika Universitas Negeri Medan Medan, 20221, Indonesia pembelajaran yang terkait dengan kurikulum, cara penyajian materi pelajaran, dan pendekatan pembelajaran yang dilakukan oleh guru". Sehingga dalam belajar ada yang merasa takut, ada yang merasa bosan bahkan ada yang alergi pada pelajaran matematika. Akibatnya, siswa tidak mampu mandiri dan tidak tahu apa yang harus dilakukannya sehingga kemampuan pemahaman matematis dan berpikir kreatif matematis siswa rendah kualitasnya saat pembelajaran berlangsung.

Munandar (2012) mengatakan bahwa siswa Indonesia mencapai peringkat terendah dalam skor kreativitas dalam tes berpikir kreatif yang diikuti delapan negara. Begitu juga Rosnawati (2011) mengemukakan bahwa rata-rata persentase yang paling rendah yang dicapai oleh peserta didik Indonesia adalah dalam domain kognitif pada level penalaran yaitu $17 \%$. Sejalan dengan penelitian pendahuluan di kelas VIII-1 SMP Parulian 1 Medan bahwa kemampuan penalaran dan berpikir kreatif matematis siswa dalam memecahkan masalah dinyatakan dalam kategori rata-rata rendah.

Dari pernyataan di atas, maka perlu diterapkan model pembelajaran penemuan terbimbing. Secara tegas Amin (Suriadi, 2006) mengemukakan bahwa suatu kegiatan "discovery atau penemuan" ialah suatu kegiatan atau pembelajaran yang dirancang sedemikian 
rupa sehingga siswa dapat menemukan konsep-konsep dan prinsip-prinsip melalui proses mentalnya sendiri. Model pembelajaran penemuan terbimbing dapat mengarahkan dan membimbing siswa untuk dapat memahami konsep dan berpikir matematik, menjelaskan keterkaitan antarkonsep dan mengaplikasikan konsep atau algoritma, secara luwes, akurat, efisien, dan tepat, dalam pemecahan masalah serta dapat menggunakan penalaran pada pola dan sifat, melakukan manipulasi matematika dalam membuat generalisasi, menyusun bukti, atau menjelaskan gagasan dan pernyataan matematika untuk dapat meningkatkan kemampuan pemahaman dan penalaran matematik siswa.

Jadi, pembelajaran model penemuan terbimbing merupakan model yang sesuai diterapkan untuk menganalisis kemampuan penalaran matematis siswa berbasis metakognisi. Di samping itu juga model penemuan terbimbing merupakan salah satu model pembelajaran yang diarahkan dalam penerapan kurikulum di Indonesia saat ini. Berdasarkan permasalahan di atas, peneliti berminat untuk melakukan penelitian tentang "Analisis Kemampuan Penalaran dan Berpikir Kreatif Matematis Siswa dalam Pembelajaran Penemuan Terbimbing".

\section{KAJIAN TEORI}

\section{Kemampuan Penalaran Matematis}

Brodie, (2010) menyatakan bahwa, "Mathematical reasoning is reasoning about and with the object of mathematics". Mathematical reasoning: thinking through math problems logically in order to arrive at solutions. It involves being able to identify what is important and unimportant in solving a problem and to explain or justify a solution.

Indikator penalaran matematika menurut Hasratuddin (2018) adalah sebagai berikut:

1) Mampu mengajukan dugaan (conjecture)

2) Memberikan alasan atau bukti terhadap kebenaran suatu pernyataan

3) Menarik kesimpulan dari suatu pernyataan

4) Memeriksa keshahihan argument

5) Menemukan pola pada suatu gejala matematis

6) Memberikan alternatif bagi suatu argumen

\section{Kemampuan Berpikir Kreatif Matematis}

Pada dasarnya berpikir kreatif metamtis merupakan kemampuan matematis esensial yang perlu dikuasai dan dikembangkan pada siswa yang belajar matematika. Munandar (2012) menyatakan bahwa kreativitas adalah kemampuan untuk menghasilkan atau menciptakan sesuatu yang baru dan kreativitas juga dapat diartikan sebagai kemampuan untuk membuat kombinasi-kombinasi yang baru.

Munandar menguraikan indikator berpikir kreatif secara rinci sebagai berikut:

1. Kelancaran meliputi:

a) Mencetuskan banyak ide, banyak jawaban, banyak penyelesaian masalah, banyak pertanyaan dengan lancar

b) Memberikan banyak cara atau saran untuk melakukan berbagai hal c) Memikirkan lebih dari satu jawaban

2. Kelenturan meliputi:

a) Menghasilkan gagasan, jawaban, atau pertanyaan yang bervariasi

b) Melihat suatu masalah dari sudut pandang yang berbeda-beda

c) Mencari banyak alternative atau arah yang berbeda-beda

d) Mampu mengubah cara pendekatan atau cara pemikiran

3. Keaslian meliputi:

a) Mampu melahirkan ungkapan yang baru dan unik

b) Memikirkan cara yang tidak lazim

c) Mampu membuat kombinasi-kombinasi yang tidak lazim dari bagian-bagiannya

4. Elaborasi meliputi:

a) Mampu memperkaya dan mengembangkan suatu gagasan atau produk

b) Menambah atau merinci detail-detail dari suatu objek, gagasan, atau situasi sehingga menjadi lebih menarik (Hendriana, dkk., 2017).

\section{Proses Berpikir Kreatif dalam Matematis}

Wallas (Munandar, 2012) menyatakan empat tahap dalam proses kreatif yaitu: persiapan, inkubasi, iluminasi, dan verifikasi. Dengan penjelasan dalam tahap persiapan, pada tahap ini seseorang mempersiapkan diri untuk memecahkan masalah dengan cara mengumpulkan data yang relevan. Pada tahap inkubasi, pada tahapan ini seseorang seakan-akan melepaskan diri secara sementara dari masalah tersebut dan tahapan ini sebagai awal proses timbulnya inspirasi yang merupakan titik mula dari penemuan baru dari prasadar. Pada tahap iluminasi, tahapan ini seseorang mendapatkan solusi pemecahan masalah yang diikuti dengan munculnya inspirasi atau gagasan baru. Pada tahap verifikasi, pada tahapan ini adalah tahap seseorang menguji dan memeriksa pemecahan masalah terhadap realita.

\section{Kesulitan Belajar Siswa dalam Pembelajaran Matematika}

Begle (dalam Siahaan, 2006) menguraikan bahwa objek matematika dalam kesulitannya yang terdiri dari empat macam yaitu: fakta, konsep, prosedur, dan prinsip. Dengan penjelasan sebagai berikut:

1. Kesulitan fakta

- Siswa tidak mampu memahami lambing-lambang dan simbol-simbol matematika

- Ketidakmampuan siswa menghapal dan membedakan lambang-lambang dan simbolsimbol matematika

2. Kesulitan konsep

- Ketidakmampuan siswa memahamin konsep dan menerapkan konsep dalam pemahaman sendiri dalam memecahkan masalah

- Ketidakmampuan siswa memahami contoh dan bukan contoh

- Ketidakmampuan siswa menyatakan arti dan istilah yang mewakili konsep tertentu

3. Kesulitan prosedur 
Vol. 14, No. 1, Juni 2021

- Ketidakmampuan siswa merencanakan, menyelesaikan,dan menguraikan langkah-langkah penyelesaian masalah matematika

- Ketidakmampuan siswa menggunakan algoritma yang tepat

4. Kesulitan prinsip

- Ketidakmampuan siswa dalam menerapkan aturan-aturan atau rumus-rumus matematika dalam memecahkan masalah

- Ketidakmampuan siswa melakukan kegiatan penemuan tentang sesuatu dan tidak teliti dalam perhitungan dan operasi aljabar

- Ketidakmampuan siswa menghubungkan antar matematika dalam pemecahan masalah

- Siswa dapat menyatakan suatu prinsip tetapi tidak dapat menguraikan artinya dan tidak dapat menerapkan prinsip tersebut

\section{Model Penemuan Terbimbing}

Bruner (Dahar, 1996) menyatakan bahwa belajar penemuan sesuai dengan mencari pengetahuan secara aktif oleh manusia, dan dengan sendirinya memberi hasil yang lebih baik. Berusaha sendiri untuk mencari pemecahan masalah serta pengetahuan menyertainya, menghasilkan pengetahuan yang benar-benar bermakna. Belajar discovery ini dapat menimbulkan rasa percaya diri pada siswa untuk mengemukakan ide atau gagasan terhadap materi yang sedang dipelajari. Dalam belajar discovery siswa tidak menerima semua informasi pengetahuan dari guru, tetapi berusaha untuk menemukan apa yang telah ditetapkan dalam tujuan pembelajaran. Siswa harus berperan aktif di dalam proses belajar yang terjadi di dalam kelas.

Castronova (Suriadi, 2006) mengemukakan ada empat fokus utama keuntungan pembelajaran penemuan terbimbing dibandingkan dengan pembelajaran biasa, yaitu : (1) motivasi. (2) daya ingat. (3) prestasi dan (4) pemindahan/ tranfer pengetahuan. Pembelajaran penemuan memungkinkan siswa untuk mencari informasi yang memuaskan rasa ingin tahu mereka. Pembelajaran ini memberikan kesempatan kepada siswa untuk mengeksplorasi keinginankeinginan mereka dan menciptakan lingkungan pembelajaran yang lebih melibatkan. Siswa lebih termotivasi dibandingkan siswa yang diajarkan dengan metode biasa.

Maka penemuan terbimbing yang dimaksud dalam penelitian ini yaitu proses dimana siswa berfikir, mengamati, mencerna, mengerti, membuat dugaan, menjelaskan, menganalisis sehingga dapat mengkonstruksi dan menemukan sendiri prinsip umum yang diinginkan dengan bimbingan dan petunjuk dari guru dan lembar kerjanya, berupa pertanyaanpertanyaan yang mengarahkan.

\section{METODE PENELITIAN}

Penelitian ini adalah penelitian kualitatif deskriptif dengan menggunakan metode studi kasus. Menurut Moleong (2016) bahwa, penelitian kualitatif adalah penelitian yang bermaksud untuk memahami fenomena apa yang dialami oleh subjek penelitian misalnya perilaku, persepsi, motivasi, tindakan, dan lain-lain.
Secara holistik dan dengan cara deskripsi dalam bentuk kata-kata dan bahasa, pada suatu konteks khusus alamiah dan dengan memanfaatkan berbagai metode alamiah.

Penelitian ini dilaksanakan pada satu kelas yaitu di kelas VII-1 SMP Parulian 1 Medan dengan sebanyak 28 orang siswa dengan materi ajar matematika yaitu perbandingan, pada tahun pelajaran 2020/2021. Instrument tes kemampuan penalaran matematis dan Berpikir Kreatif matematis dengan sebanyak empat soal uraian.

Teknik analisis data dalam penelitian kualitatif dengan menggunakan langkah-langkah analisis data Miles \& Huberman ditunjukkan pada Gambar 1.

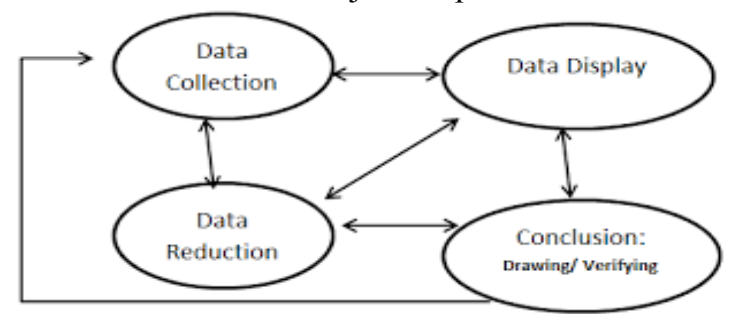

Gambar 1. Komponen Data Analisis Model Miles \& Huberman

Berdasarkan Gambar 1 di atas bahwa setelah melakukan pengumpulan data, maka peneliti melakukan antisipatori sebelum melakukan reduksi data. Skor setiap siswa ditentukan berdasarkan hasil tes yaitu tes berpikir kreatif matematis. Semua lembar jawaban dari hasil tes dikumpulkan untuk diperiksa dan diberi skor menurut pedoman penskoran.

Untuk penentuan standar minimal berpedoman pada kriteria ketuntasan minimal $\geq 65$. Nilai pengetahuan dan keterampilan siswa ditentukan dengan rumus berikut:

$$
\text { Nilai siswa }=\frac{\text { Skor yang diperoleh }}{\text { Skor maksimum }} \times 4
$$

Berdasarkan pandangan tersebut, hasil tes kemampuan penalaran matematis dapat disajikan dalam interval kriteria dalam Tabel 1 berikut:

Tabel 1. Tingkat Kemampuan Penalaran Matematis Siswa

\begin{tabular}{lc}
\hline \multicolumn{1}{c}{ Interval Skor } & Kriteria \\
\hline $0 \leq$ SKPM $<65$ & Tinggi \\
\hline $65 \leq$ SKPM $<80$ & Sedang \\
\hline $80 \leq$ SKPM $<100$ & Rendah \\
\hline
\end{tabular}

Keterangan: SKPM = Skor Kemampuan Penalaran Matematis (Wulandari, 2018)

Sedangkan berdasarkan pandangan tersebut, hasil tes kemampuan berpikir kreatif matematis dapat disajikan dalam interval kriteria dalam Tabel 2. Untuk mengecek keabsahan data akan digunakan teknik triangulasi. Menurut Moleong (2016) menyatakan, triangulasi merupakan teknik pemeriksaan keabsahan data dengan memanfaatkan sesuatu di luar data itu, untuk pengecekan atau sebagai pembanding kepada data itu. 
Vol. 14, No. 1, Juni 2021

Tabel 2. Tingkat Kemampuan Bepikir Kreatif

Matematis Siswa

\begin{tabular}{cc}
\hline Interval Skor & Kriteria \\
\hline $0 \leq$ SKBKM $<65$ & Tinggi \\
\hline $65 \leq$ SKBKM $<80$ & Sedang \\
\hline $80 \leq$ SKBKM $<100$ & Rendah \\
\hline
\end{tabular}

Keterangan: SKBKM $=$ Skor Kemampuan Berpikir Kreatif Matematis (Wulandari, 2018)

\section{HASIL PENELITIAN}

\section{Deskripsi Tingkat Kemampuan Penalaran Matematis Siswa}

Berdasarkan hasil tes kemampuan Penalaran matematis siswa maka, diperoleh tingkat kemampuan penalaran matematis siswa sebagai berikut:

Tabel 3. Deskripsi Tingkat Kemampuan Penalaran Matematis Siswa

\begin{tabular}{ccc}
\hline $\begin{array}{c}\text { Tingkat Penalaran } \\
\text { Matematis Siswa }\end{array}$ & Jumlah Siswa & Persentase \\
\hline Tinggi & 8 & $28,57 \%$ \\
\hline Sedang & 14 & $50,00 \%$ \\
\hline Rendah & 6 & $21,42 \%$ \\
\hline
\end{tabular}

2. Deskripsi Tingkat Kemampuan Berpikir Kreatif Matematis Siswa

Berdasarkan hasil tes kemampuan berpikir kreatif matematis siswa maka, diperoleh tingkat kemampuan berpikir kreatif matematis siswa sebagai berikut:

Tabel 4. Deskripsi Tingkat Kemampuan Berpikir Kreatif Matematis Siswa

\begin{tabular}{ccc}
\hline $\begin{array}{c}\text { Tingkat Berpikir Kreatif } \\
\text { Matematis Siswa }\end{array}$ & Jumlah Siswa & Persentase \\
\hline Tinggi & 5 & $17,85 \%$ \\
\hline Sedang & 10 & $35,71 \%$ \\
\hline Rendah & 13 & $46,42 \%$ \\
\hline
\end{tabular}

3. Deskripsi Indikator Penalaran dan Berpikir Kreatif Matematis Yang Dominan Dalam Pembelajaran

Berdasarkan data penelitian bahwa untuk setiap kategori kemampuan penalaran (tinggi, sedang, rendah), siswa memiliki minimal 1 indikator berpikir kreatif yang paling dominan yang bervariasi antar siswa. Dalam kategori siswa yang memiliki kemampuan penalaran baik, dominan berpikir kreatif matematis, indikator yang paling banyak diperoleh dari 8 siswa adalah indikator Fleksibilitas yaitu 4 siswa. Dalam kategori siswa dengan kemampuan penalaran yang sedang, indikator berpikir kreatif matematis yang dominan yaitu yang paling banyak diperoleh dari 8 siswa adalah indikator kelancaran dan indikator originalitas yang masing-masing 4 siswa. Dan pada kategori siswa dengan kemampuan penalaran rendah, berpikir kreatif matematis dominan, Indikator yang paling banyak diperoleh dari 10 siswa adalah indikator Orisinalitas yaitu sebanyak 6 siswa. Berdasarkan data tersebut juga dapat dikatakan bahwa indikator Orisinalitas merupakan indikator yang paling dominan diperoleh oleh siswa. Artinya, siswa paling dominan dalam memecahkan masalah dengan caranya sendiri atau mampu memberikan cara lain untuk memecahkan masalah matematika yang disediakan.

\section{Analisis Kesulitan Pemecahan Masalah Kemampuan Penalaran Matematis Siswa dan Kemampuan Berpikir Kreatif Matematis Siswa Dalam Matematika}

Kesulitan proses berpikir kreatif siswa dalam pembelajaran penemuan terbimbing sambil mengerjakan masalah. Untuk menganalisisnya, diambil beberapa siswa untuk mewakili setiap kategori. Dalam kategori tinggi, siswa melakukan tidak mengalami kesulitan yang berarti dalam menyelesaikan masalah yang diberikan. Dalam kategori sedang, siswa memiliki kesulitan menyelesaikan soal yang diberikan. Pada kategori rendah, siswa mengalami kesulitan menuliskan apa yang diketahui dan ditanyakan dalam masalah, memahami masalah yang terkandung dalam masalah. Kesulitan proses pemecahan masalah siswa dalam pembelajaran penemuan terbimbing saat mengerjakan pemecahan masalah. Untuk menganalisisnya, diambil beberapa siswa untuk mewakili setiap kategori. Dalam salah satu kategori, siswa dapat mudah memahami masalah yang diberikan dengan baik. Dalam kategori cukup, siswa sudah dapat memahami masalah baik, tetapi masih salah pada solusi akhir. Pada kategori kurang, siswa merasa sangat sulit untuk memahami pertanyaan-pertanyaan yang diberikan.

\section{PEMBAHASAN HASIL PENELITIAN}

Dalam proses pembelajaran yang dilaksanakan selama tiga pertemuan di kelas VII-1 SMP Parulian 1 Medan bahwa keaktifan siswa semakin bagus setelah diberlakukan model pembelajaran Penemuan Terbimbing dibandingkan dengan pembelajaran sebelumnya yang masih menggunakan pembelajaran konvensional berupa ceramah atau menjelaskan teori saja. Sembari pembelajaran menekankan model pembelajaran yang berpusat pada siswa juga diperlukan kemampuan penalaran matematis berbasis metakognisi siswa dapat dilatihkan, dibiasakan, hingga membudaya dengan baik melalui interaksi antar siswa dan guru.

Proses penalaran siswa berdasarkan indikator penalaran terdiri dari kemampuan melakukan manipulasi matematis, kemampuan memeriksa kesahihan suatu argument, kemampuan menarik kesimpulan. Kesulitan siswa dalam penelitian ini tidak terlepas dari kesulitan pada objek matematika pada fakta, konsep, prinsip dan prosedur. Menurut pendapat Syah (2002) menyatakan, fenomena kesulitan belajar seorang siswa biasanya tampak jelas dari menurunnya kinerja akademik atau prestasi belajar. Kesulitan dalam penelitian ini, sejalan dengan pendapat Begle (Siahaan, 2006) tentang kesulitan siswa dalam menyelesaikan masalah pada objek matematika terdiri dari empat macam, yaitu (1) fakta, (2) konsep, (3) prosedur, (4) prinsip. Dalam pembahasan kesulitan pada siswa dalam penelitian ini berhubungan dengan proses bernalarnya.

Siswa yang kemampuan penalaran kategori tinggi, 
mampu menyelesaikan masalah yang diberikan dan ratarata mampu mencapai indikator penalaran. Sejalan dengan hasil penelitian Maharani \& dkk (2017) menyatakan bahwa siswa dengan kemampuan tinggi pada proses bernalar pada proses tahap persiapan memahami masalah dan memiliki pengetahuan untuk menyelesaikan masalah. Dengan kata lain, bahwa siswa kemampuan tinggi melakukan proses bernalar dengan baik.

Siswa kemampuan penalaran matematis kategori sedang, dimana mereka mampu memberikan keterangan dari soal dengan membuat diketahui dan yang ditanyakan dari soal. Maka, dapat dikatakan mereka tidak mengalami adanya kesulitan dalam proses ini karena memahami fakta permasalahan. Sehingga tidak membutuhkan waktu lama dalam mengendapkan masalah untuk menemukan ide dengan menghasilkan berbagai ide temuan yang sama dan yang berbeda dengan demikian mereka tidak mengalami adanya kesulitan dalam menentukan ide.

Kesulitan dalam prosedur yaitu ketidakmampuan siswa menyelesaikan masalah menguraikan langkah penyelesaiannya. Siswa yang kemampuan penalaran matematis kategori sedang umumnya mereka mampu melakukan verifikasi jawaban dari penyelesaian setiap masalah. Selanjutnya, pada proses bernalar dalam menyelesaikan, siswa yang memiliki kemampuan penalaran matematis kategori sedang, ide awal yang menjadi solusi dan memecahkan masalah akan tetapi mereka mengalami kesulitan dalam menentukan rumus penyelesaian yang tepat, selain itu prosedur penyelesaian yang tidak sesuai aturannya. Pada tahap akhir, mereka tidak melakukan pemeriksaan ulang pada lembar jawaban dari masalah yang diselesaikannya.

Berdasarkan hasil penelitian Setiawani \& dkk (2019) bahwa siswa yang masuk kategori sedang mampu memahami masalah dengan baik. Mereka dapat mengidentifikasi elemen-elemen yang diketahui dan ditanyakan, dan kecukupan elemen-elemen yang dibutuhkan. Selain mengidentifikasi data yang diketahui atau data yang ditanyakan dengan benar, siswa juga dapat menyampaikannya dengan cara mereka sendiri. Meskipun agak rumit untuk menyampaikannya, tetapi inti masalahnya dapat disampaikan dengan benar.

Selanjutnya, siswa berkemampuan penalaran matematis kategori rendah, membutuhkan waktu yang lama dalam mengendapkan masalah untuk menemukan ide. Sehingga untuk solusi pemecahan masalah berdasarkan kemampuan bernalar dalam memecahkan serta mengembangkan pemecahan masalah ditemukan adanya kesulitan siswa dalam menyelesaikan masalah. Kesulitan yang ditemukan disaat menyelesaikan masalah adalah kesulitan dalam menentukan konsep yang tepat, kesulitan dalam memahami konsep masalah, kesulitan dalam menerapkan rumus penyelesaian (prinsip), kesulitan dalam operasi hitung serta prosedur penyelesaian yang tidak sesuai dengan aturannya. Dengan demikian siswa berkemampuan rendah tidak mampu memeriksa ulang penyelesaian dari jawaban mereka serta tidak memberikan keterangan atau kesimpulan akhir dari setiap jawaban.
Sejalan dengan pendapat Maharani (2017) menyatakan bahwa siswa dalam kategori lebih rendah dari awal mereka sudah mengalami kesulitan. Mereka tidak mengerti dengan soal dan tugas matematika yang diberikan. Selain itu, mereka tidak memiliki informasi atau pengetahuan yang dapat digunakan untuk menyelesaikan masalah. Akibatnya, siswa tidak jelas dalam mengimplementasikan ide untuk menyelesaikan masalah dan solusi yang didapat juga salah.

Hal ini sejalan dengan penelitian Lestari \& dkk (2018) menyatakan kelompok yang lebih rendah dapat memahami masalah dengan menuliskan apa yang diketahui dari masalah. Lebih lanjut, mereka dapat menggunakan konsep/formula dan menyadari kesalahan konsep tetapi mereka tidak tahu cara memperbaikinya. Umumnya siswa kelompok bawah membuat lebih banyak kesalahan pemahaman dan kebingungan dalam memilih strategi penyelesaian daripada siswa kelompok atas.

Kemudian untuk kemampuan berpikir kreatif dengan kemampuan "rendah" sebanyak 46,42\% berjumlah 13 siswa, kemampuan "sedang" sebanyak $35,71 \%$ berjumlah 10 siswa, dan kemampuan "tinggi" sebanyak $17,85 \%$ berjumlah 5 siswa. Pada indikator kemampuan berpikir kreatif matematis siswa yaitu (1) indikator Fluency kategori penilaian "Tinggi” sebanyak 5 siswa mampu memberikan beberapa ide atau cara dalam menyelesaikan masalah, (2) indikator Fleksibility kategori penilaian "Sedang" sebanyak 10 siswa sudah mampu menyelesaikan masalah dari sudut pandang yang berbeda dan mengarah pada penyelesaian yang benar dalam menyelesaikan soal namun kurang tepat, (3) indikator Originality kategori penilaian "Sedang" sebanyak 12 siswa mampu menyelesaikan masalah dengan caranya sendiri, (4) indikator Elaborasi kategori penilaian "Sedang" sebanyak 4 siswa mampu mengembangkan atau memperkaya gagasan secara merinci. Hal ini sejalan dengan Sagala (2015), PPs Universitas Negeri Medan melakukan penelitian yang bertujuan salah satunya menganalisis kualitas kemampuan berpikir kreatif siswa dalam penerapan model Pembelajaran Pencapaian Konsep. Hasil penelitian menunjukkan kemampuan pemahaman konsep matematika siswa yang diberikan pembelajaran secara kuantitatif adalah $12,5 \%$ pada kategori tinggi, 46,9\% pada kategori sedang dan $40,6 \%$ pada kategori rendah.

\section{KESIMPULAN}

Berdasarkan hasil analisis data, dapat disimpulkan proses penalaran dan berpikir kreatif matematis siswa dalam pembelajaran penemuan terbimbing.

1. Kemampuan penalaran matematis siswa dengan model pembelajaran penemuan terbimbing. Ada 8 siswa $(28,57 \%)$ kategori tinggi, 14 siswa $(50,00 \%)$ kategori sedang, dan 6 siswa $(21,42 \%)$ kategori rendah. Sedangkan siswa kemampuan berpikir kreatif matematis dengan model pembelajaran berbasis masalah. Ada 5 siswa dengan berkemampuan tinggi $(17,85 \%), \quad 10$ siswa berkemampuan sedang $(35,71 \%)$, dan 13 siswa berkemampuan rendah $(46,42 \%)$. 
Vol. 14, No. 1, Juni 2021

2. Proses jawaban siswa dideskripsikan maka disimpulkan bahwa: a) tingkat penalaran siswa pada kategori tinggi adalah nominan siswa menyelesaikan masalah mencapai indikator penalaran dan berpikir kreatif dengan sedikit mengalami kesulitan. b) tingkat penalaran siswa pada kategori sedang adalah nominan siswa menyelesaikan masalah pada indikator mampu mengajukan dugaan (conjecture), mampu memberikan alasan atau bukti terhadap kebenaran suatu pernyataan, mampu menarik kesimpulan dari suatu pernyataan, dan mampu memeriksa keshahihan argument, Sedangkan pada kemampuan berpikir kreatif matematis tingkat sedang bahwa proses jawaban siswa memenuhi tahapan persiapan, inkubasi, iluminasi dan ada beberapa siswa tidak mencapai tahapan verifikasi c) tingkat penalaran siswa pada kategori rendah adalah nominan siswa tidak mampu mencapai indikator penalaran, sedangkan siswa dengan kemampuan berpikir kreatif matematis tingkat rendah dengan proses jawaban yang tidak memenuhi tahapan iluminasi dan verifikasi.

3. Kesulitan proses bernalar siswa dalam pemecahan masalah dalam pembelajaran penemuan terbimbing saat mengerjakan permasalahan. Untuk menganalisisnya, diambil beberapa siswa untuk mewakili setiap kategori. Dalam kategori baik, siswa dapat dengan mudah memahami masalah yang diberikan dengan baik. Dalam kategori cukup, siswa sudah dapat memahami masalah dengan baik, tetapi masih salah pada solusi akhir. Pada kategori kurang, siswa merasa sangat sulit memahami pertanyaan yang diberikan. Sedangkan kesulitan proses berpikir kreatif siswa dalam pembelajaran penemuan terbimbing dalam mengerjakan masalah. Untuk menganalisisnya, diambil beberapa siswa untuk mewakili setiap kategori. Dalam kategori tinggi, siswa tidak mengalami kesulitan yang berarti dalam menyelesaikan masalah yang diberikan. Dalam kategori sedang, siswa mengalami kesulitan dalam menyelesaikan soal yang diberikan. Pada kategori rendah, siswa mengalami kesulitan menuliskan apa yang diketahui dan ditanyakan dalam masalah, memahami masalah yang terdapat dalam masalah. Sehingga kesulitan yang dialami oleh siswa yaitu pada kategori sedang dan rendah yang mencakup pada kesulitan fakta, konsep, prinsip, dan prosedur.

\section{UCAPAN TERIMAKASIH}

Pada kesempatan ini penulis mengucapkan terimakasih yang tulus dan penghargaan setinggitingginya kepada semua pihak yang telah membantu penulis, kepada keluarga penulis yang telah mendukung dalam segala hal. Bapak Prof. Dr. Bornok Sinaga, M.Pd, bapak Dr. Waminton Rajagukguk, M.Pd, yang telah meluangkan waktu dan pikirannya untuk membantu penulis. Kepala Sekolah SMKS Parulian 1 Medan, serta guru-guru dan staf pegawai yang telah memberikan izin untuk melakukan penelitian di sekolah tersebut.
REFERENSI

Abdurrahman. 2012. Anak Berkesulitan Belajar. Jakarta: Rineka Cipta.

Akman, Ozkan \& Alagoz, Bulent. 2018. Relation between Metacognitive Awareness and Participation to Class Discussion of University Students. Universal Journal of Educational Research. 6(1):11-24. Doi: 10.13189/UJER.2019.060102.

Brodie, K. 2010. Teaching Mathematical Reasoning in Secondary School Classroom. New York: Springer.

Dahar, R.W. 1996Teori-teori Belajar. Jakarta: Erlangga

Hasratuddin. 2018. Mengapa harus Belajar Matematika ?. Edira. ISBN: 987-602-6970-45-9

Hendriana, H., Rohaeti, E \& Sumarmo, U. 2017. Hard Skills and Soft Skills. Bandung: PT. Refika Aditama.

Jayapraba,G. 2013. Metacognitive Instruction and Cooperative Learning-Strategies For Promoting Insightful Learning In Science. Research Scholar. University Tirunelveli India. International Journal on New Trends in Education and Their Implications. 4(5):165-172.

Lauren, sTheresia. 2010. Penjenjangan Metakognisi Siswa yang Valid Dan Reliabilitas. Jurnal Pendidikan dan Pembelajaran. Vol. 17. No. 2.

Lestari, Wahyu,. Pratama, L.D \& Jailani. 2018. Metacognitive Skills in Mathematics Problem Solving. Jurnal Inovasi Pendidikan Matematika. Volume 6. No. 3.

Maharani. H. R., Sukestiyarno, and Waluya. Budi. 2017. Creative Thinking Process Based on Wallas Model in Solving Mathematics Problem. International Journal on Emerging Mathematics Education (IJEME), Vol. 1, No. 2, September 2017, pp. 177-184, P-ISSN: 2549-4996, E-ISSN: 25485806 ,

Doi: http://dx.doi.org/10.12928/ijeme.v1i2.5783.

Moleong, Lexy J. 2016. Metodologi Penelitian Kualitatif. Bandung: PT. Remaja Rosdakarya Offset.

Munandar, Utami. 2012. Kreativitas dan Keberbakatan Strategi Mewujudkan Potensi Kreatif dan Bakat. Jakarta: PT. Grasindo.

North Central Regional Educational Laboratory (NCREL). 2007. Metacognition. (Online),http://www.ncrel.org/sdrs/areasissues/stud ents/learning/lrlmetn.html, diakses 20 November 2017.

Rusman. 2014. Model-Model Pembelajaran: Mengembangkan Profesionalisme Guru. Jakarta: PT. Raja Grafindo.

Rosnawati. R. (2011). Kemampuan penalaran matematika siswa smp indonesia pada timss 2011. Jurnal UNY. Yogyakarta: Tidak Diterbitkan

Setiawani, S., Fatahillah, A., Oktavianingtyas, E \& Wardani, D.Y. 2019. The Student's Creative Thinking Process in Solving Mathematics Problem Based on Wallas' Stages. IOP Conf. Series: Earth and Environmental Science. Doi:10.1088/17551315/243/1/012052. 
Vol. 14, No. 1, Juni 2021

Siahaan, S. 2006. Artikel Teaching Grant:3-4;23-30. Medan: Universitas Negeri Medan.

Sinaga, Bornok. 2007. Buku Model PBM-B3. Surabaya: PPs Universitas Negeri Surabaya.

Suriadi. 2006. Pembelajaran Dengan Pendekatab Discovery yang Menekankan Aspek Analogi untuk Meningkatkkan Pemahaman Matematik Kemampuan Berpikir Kritis Siswa SMA. Tesis. PPs UPI; Tidak diterbitkan

Syah, Muhibbin.2002.Psikologi Belajar.Jakarta: PT. Raja Grafindo Persada.

Trianto. 2011. Mendesain Model-Model Pembelajaran Inovatif-Progresif. Jakarta: Kencana Prenada Media Group.

Wallas, G. 1926. The Art of Thought. London: Jonathan Cape.

Wulandari. 2018. Analisis Kemampuan Metakognisi Siswa dalam Pemecahan Masalah Matematis pada Pembelajaran Berbasis Masalah di SMA Negeri 1 Binjai. Tesis. Pps Unimed. 